\title{
Development of Science Learning Set on the Topic of Changing Objects Around Us
}

\author{
Maulida Rakhmi ${ }^{*}$, Suryajaya, Muhammad Zaini \\ Masters Program of Natural Sciences Teaching, Lambung Mangkurat University, Banjarmasin, Indonesia
}

\author{
DOI: $10.36348 /$ jaep.2020.v04i03.006 $\quad$ | Received: 07.03.2020 | Accepted: 14.03 .2020 | Published: 21.03 .2020 \\ *Corresponding author: Maulida Rakhmi
}

\section{Abstract}

Difficulties in learning science especially in critical thinking skills are characterized by low mastery of concepts, misconceptions, and those related to contextual matters. Specifically developed learning set will be able to increase students' mastery of critical thinking skills. This research development aims to evaluate the validity, practicality, and effectiveness of the development of science learning set to develop critical thinking skills of junior high school students. The research subjects were $7^{\text {th }}$ grade students of Muhammadiyah 3 MTs Al-Furqan Banjarmasin. The validity data of the learning set was obtained through the assessment of 3 experts. Data on the practicality of learning set include evaluating the implementation of lesson plans and students' responses to the small group test. Data about the effectiveness of learning set include: 1) the results of students' critical thinking skills; 2) cognitive assessment results. Data was collected through tests and observations and analyzed descriptively. The results showed that the science learning set developed were classified as valid based on the results of the validation, including the design of the learning set, format, material, language, presentation, supporting innovation and improving the quality of teaching and learning activities. Learning devices are also declared practical because they are easy to use by students. This is supported by: 1) The implementation of lesson plans in small group tests scores from the lowest 3.00 to the highest 4.00 in the practical to very practical categories; 2) Students give positive responses to the learning process. The effectiveness of science learning set has also been fulfilled, this is based on the findings of the study: 1) students' critical thinking skills in the field test are at least good categories; and 2) students' cognitive learning outcomes through field tests are in the good category $(80 \leq 100 \%)$.

Keywords: Natural learning set, critical thinking, effectiveness.

Copyright @ 2020: This is an open-access article distributed under the terms of the Creative Commons Attribution license which permits unrestricted use, distribution, and reproduction in any medium for non-commercial use (NonCommercial, or CC-BY-NC) provided the original author and sources are credited.

\section{INTRODUCTION}

Learning is an activity carried out by someone in order to have competencies in the form of skills and knowledge needed. Learning can also be seen as an elaboration process in the search for meaning carried out by individuals [1]. Therefore the skills and knowledge possessed by students should be the results obtained through the ability to think and find. Thus, any knowledge possessed by students will last longer because the truth is obtained by the students themselves.

Natural Sciences is one of the basic sciences that has an important role in the mastery of science and technology, as well as science that aims to educate humans to be able to think logically, critically, rationally, and confidently. Understanding, mastery of the material and students' learning achievement are indicators of the success of the science learning process. The higher the understanding and mastery of the material and learning achievement, the higher the level of learning success. But in reality, science learning achievement achieved by students is still low. The still low quality of student learning outcomes is an indication that the objectives set in the science curriculum have not been reached optimally. The low achievement of science learning is also caused by critical thinking skills in learning which are still very low.

According to TIMSS [7], from the results of the Global Institute Trends in International Math and Science (TIMSS) Survey in 2007 and 2011 noted that only 5 percent of Indonesian students were able to work on high category questions that required reasoning, 78 percent of Indonesian students could work on questions low category that only requires memorization. In addition to the 2015 Program for International Student Assessment (PISA) record, Indonesia ranks 9th out of the 70 participating PISA countries [3]. The results of a 
survey of the two institutions, give a general picture of the ability of students in Indonesia to be at the lowest cognitive level, namely knowing (knowing) means that students' critical thinking skills are still low. Indonesian students have not been able to apply their basic knowledge to solve problems, have not been able to understand and apply knowledge in complex problems (applying), make conclusions, and arrange generalizations (reasoning).

From this phenomenon in order to be able to face the challenges of the 21 st century, high quality human resources are needed who have various abilities, including critical thinking skills. The learning process that has taken place in schools is in accordance with the Implementation of the 2013 Curriculum which aims to train and develop students' skills.

Learning set are a number of materials, set, media, instructions and guidelines that will be used by a teacher in the learning process in class. A teacher needs learning set that are not only as a guide but as a benchmark and increase professionalism. The purpose of the learning device is to fulfill the success of a teacher in implementing the learning process.

Science concepts are concepts that are considered difficult by most students. Material Changes in surrounding objects are material that is very closely related to the daily scope of students, but there are many microscopic concepts that are difficult for students to understand. This difficult concept must be able to be arranged by a science teacher by creating a learning process that is stimulus and is able to create students' responses to be interested in the concept of science. The stimulus referred to can be in the form of presentation of interesting material, development of interesting science experiments, application of daily life and optimizing students to be actively involved [4].

Based on the reality on the ground, the teacher already has a device that is in accordance with the 2013 curriculum, but the device used by science teachers in MTs grade $7^{\text {th }}$ on the concept of Changing Things Around Still cannot be said to meet what is expected from the things that have been revealed above, both on the selection of models, learning methods and the preparation of teaching materials. So the teacher needs to have the right learning set and models to carry out the task in accordance with the objectives. One learning model that can be applied by teachers in the classroom is the Guided Inquiry learning model. Inquiry learning model is a learning model that places students at the center of the learning process in the classroom.

Rooney [5] states that by using inquiry learning can change learners' learning styles, students become more involved and actively participate in learning, take responsibility for their own work and students become more enjoy learning of inquiry and show positive attitudes in their learning activities. students should be taught to use scientific inquiry and develop the ability to think and act in ways that are related to discovery (inquiry), so that inquiry learning is very appropriate to be used to practice students' critical thinking skills.

\section{RESEARCH METHODS}

This research development uses Tessmer's formative evaluation design. Tessmer's formative evaluation design aims to improve the product. The steps are through: 1) self evaluation, 2) expert opinion, 3) individual test (one to one), 4) small group test, 5) field test. Research subjects were 40 students of $7^{\text {th }}$ grade of MTs Muhammadiyah 3 Al-Furqan. The type of data collected during the micro cycle are: 1) validity data, 2) practicality data of the device, and 3) data effectiveness of the device. Types of effectiveness data include product cognitive learning outcomes, critical thinking skills, character assessment and social attitudes, and student responses.

\section{RESEARCH RESULTS AND DISCUSSION Research Results Learning Set Validation Results}

The results of the learning device validation by experts are used to determine the validity of the learning device. Experts assess learning devices consisting of; 1) Syllabus, 2) RPP, 3) Teaching material, 4) LKPD, 5) Assessment sheet. The complete syllabus validation results are in Appendix 1 and concise results are presented in Table 1.

Table-1: Learning Set Validation Results

\begin{tabular}{|l|l|c|c|}
\hline No & Validation Component & Final Score (Mode) & Category \\
\hline 1 & Syllabus & 4 & Valid \\
\hline 2 & Lesson plan & 4 & Valid \\
\hline 3 & Teaching Material & 4 & Valid \\
\hline 4 & LKS & 4 & Valid \\
\hline 5 & The assessment sheet & 4 & Valid \\
\hline
\end{tabular}

\section{Practical Results of Learning Set}

Practicality of content is obtained from opinions given by students. Opinions of students at this stage are divided into three, namely opinions on teaching materials, worksheets, and cognitive assessment sheets. Learners' opinions on the learning set are presented in Table 2. 
Table-2: Summary of Student Opinion Results Towards Learning Set

\begin{tabular}{|l|l|c|c|}
\hline No & Validation Component & Final Score (Mode) & Category \\
\hline 1 & Syllabus & 3 & Good \\
\hline 2 & Lesson plan & 3 & Good \\
\hline 3 & Teaching Material & 3 & Good \\
\hline 4 & LKS & 3 & Good \\
\hline 5 & The assessment sheet & 3 & Good \\
\hline
\end{tabular}

The practicality of learning device expectations is measured by the implementation of the lesson plans (RPP) in the process of learning activities in small group tests. The results of the small group test were carried out at $7^{\text {th }}$ grade of MTs Muhammadiyah 3 Al-Furqan Banjarmasin with a total of 6 students. The implementation of a small group test consists of two meetings. In the implementation at this stage learning is carried out by partner teachers so there is no bias. Small group trials using learning set in class are data taken from the assessment of 2 observers on the implementation of lesson plans developed by researchers. A summary of the assessment of the feasibility of learning using the science learning set with the guided inquiry model of the topic of change in form is presented in Table 3.

Table-3: Results of the Implementation of RPP in Small Group Tests

\begin{tabular}{|l|c|c|c|c|}
\hline \multicolumn{1}{|c|}{ Activities } & \multicolumn{2}{|c|}{ Session } & Score & Category \\
\cline { 2 - 5 } & $\mathbf{1}$ & $\mathbf{2}$ & & \\
\hline Pre-Teaching & 4 & 4 & 4 & Very Good \\
\hline Whilst-Teaching & & & & \\
\hline Phase 1 (Creating a Problem Formulation) & 3 & 3 & 3 & Good \\
\hline Phase 2 (Making a Hypothesis) & 3 & 4 & 3,5 & Good \\
\hline Phase 3 (Designing an Experiment) & 4 & 3 & 3,5 & Good \\
\hline Phase 4 (Gathering Data) & 4 & 4 & 4 & Very Good \\
\hline Phase 5 (Analyzing Data) & 4 & 4 & 4 & Very Good \\
\hline Phase 6 (Making Conclusions) & 4 & 4 & 4 & Very Good \\
\hline Post-Teaching & 3 & 3 & 3 & Good \\
\hline
\end{tabular}

The actual practicality of the learning kit is measured by the implementation of the lesson plan in the process of learning activities in the field test. Field test using classroom learning set is data taken from the evaluation of two observers on the implementation of lesson plans developed by researchers. A summary of the assessment of the feasibility of learning using a science learning set with a guided inquiry model of the topic of changes in surrounding objects is presented in Table 4.

Table-4

\begin{tabular}{|l|c|c|c|c|}
\hline \multicolumn{1}{|c|}{ Activities } & \multicolumn{2}{|c|}{ Session } & Score & Category \\
\cline { 2 - 4 } & $\mathbf{1}$ & $\mathbf{2}$ & & \\
\hline Pre-Teaching & 3 & 4 & 3,5 & Good \\
\hline Whilst-Teaching & & & & \\
\hline Phase 1 (Creating a Problem Formulation) & 3 & 3 & 3 & Good \\
\hline Phase 2 (Making a Hypothesis) & 4 & 4 & 4 & Very Good \\
\hline Phase 3 (Designing an Experiment) & 4 & 3 & 3,5 & Good \\
\hline Phase 4 (Gathering Data) & 4 & 3 & 3,5 & Good \\
\hline Phase 5 (Analyzing Data) & 4 & 4 & 4 & Very Good \\
\hline Phase 6 (Making Conclusions) & 4 & 4 & 4 & Very Good \\
\hline Post-Teaching & 4 & 4 & 4 & Very Good \\
\hline
\end{tabular}

\section{The Effectiveness of Learning Set} Learning Outcomes

Student learning outcomes scores obtained from cognitive learning outcomes. Cognitive learning outcomes are learning outcomes obtained after students participate in learning activities with completeness that has reached the KKM set by the school which is equal to 75 . Cognitive learning outcomes are summarized in Table 4.

Table-4: Student Cognitive Learning Outcomes

\begin{tabular}{|c|c|c|c|c|}
\hline Number of students & Completeness Pretest & Incomplete Pretest & Completeness Postest & Incomplete Postest \\
\hline 28 & 5 & 23 & 25 & 3 \\
\hline Average & 36,60 & 78,57 \\
\hline
\end{tabular}




\section{Critical Thinking Ability}

5.

The critical thinking skills of the field test group can be seen in appendix 16 and are presented briefly in Table

Table-5: Critical Thinking Skills in Field Test

\begin{tabular}{|c|l|c|c|}
\hline No & \multicolumn{1}{|c|}{ Critical thinking skills } & Average & Category \\
\hline 1. & Formulate the problem & 3.58 & Good \\
\hline 2. & Formulate a hypothesis & 3.50 & Good \\
\hline 3. & Designing Experiments/observations & 3.42 & Good \\
\hline 4. & Collecting data & 3.08 & Good \\
\hline 5. & Analyze data & 3.00 & Good \\
\hline 6. & Make conclusions & 3.50 & Good \\
\hline
\end{tabular}

$$
\begin{array}{ll}
\text { Category: } & \\
4 & =\text { Very good } \\
3 \leq 4 & =\text { Good } \\
2 \leq 3 & =\text { Quite Good } \\
1 \leq 2 & =\text { Not good } \\
\text { (adapted from Nur, 2013) }
\end{array}
$$

Results from data Table 5 shows that students' critical thinking skills are good, although there are no students who get very good categories. The highest average value of each category is 3.58 with good categories and the lowest value is 3.00 also with good categories.

\section{Discussion \\ Validity of Learning Devices}

The validity of the learning kit includes syllabus, lesson plans, LKPD and teaching materials on the topic of changes in objects around and cognitive assessment sheets. The results of the assessment by the validators namely the device as a whole are declared valid. Based on the average criteria of the validator assessment results on the syllabus validation states that the syllabus component was valid. This is because most of the indicators for evaluating syllabus validity have received optimal scores from validators. Achievement scores that are classified as valid for each indicator are obtained because in the syllabus development process the researcher has compiled the syllabus according to the instructional design rules. In addition, the development of a guided inquiry-based syllabus produced in accordance with the 2013 curriculum. This is in line with the results of Zaini \& Asnida's research [6]. Each expert evaluates a product to determine the strengths and weaknesses of a product.

The impact of a valid learning tool is that learning expectations can be carried out practically and effectively. The practicality of learning is evident from the results of the implementation of the lesson plan which is classified as very good. The effectiveness of learning is evident from the cognitive learning outcomes of products and processes that are classified as good. On the learning device, the product cognitive learning outcomes are assessed from the product cognitive tests at the end of the learning. While the results of critical thinking skills are assessed based on the assessment scores of students' activities using LKPD (worksheets).

There are some improvements made based on the recommendations of the experts, including improvements to the syllabus design, writing the RPP format, the steps of the RPP activities, the introduction of the RPP, the steps of the LKPD activities are more clearly clarified, the description of the picture must be readable, the description of the material is adjusted to the objectives, foreign language terms everything must be italicized, and text can be written to make the reader more active. Input on the improvement of equipment is needed both from the aspects of design, format, material, linguistic, presentation, and supporting innovation and improving the quality of teaching and learning activities so that it can be used as a source of learning for students. After getting advice from an expert, further improvements are made so that the learning device resulting from this development can be used at a later stage, namely to obtain practicality and effectiveness value of the device.

The results of the validation of all components of the learning device are classified as good because the developed devices have been arranged according to the characteristics of the guided inquiry model. The guided inquiry model is effective learning in building students' abilities [7]. Overall critical thinking skills and social skills of students in learning are influenced by the guided inquiry model [8]. Through learning models based on guided inquiry models with scientific methods the atmosphere of learning in the classroom becomes more student-centered so that it encourages students to be active. This is because the learning flow in the RPP motivates students to work actively solving problems. When students are active in learning activities, more knowledge will be absorbed. In addition, group activities in conducting activities in LKPD greatly support the learning environment of students. This is in line with what Maslyni [9] said that the product developed has fulfilled the validity aspect so that it can be continued in the next test.

\section{Practicality of Learning Devices}

The practicality of learning tools in this study is divided into two, namely the practicality of 
expectations and the practicality. The practicality of the device expectations is obtained through a one to one evaluation stage conducted on 3 students. Components in the assessment are in the form of the contents of teaching material, LKPD, and cognitive sheets, appearance, type and size of letters, description or explanation, language, pictures, instructions for workmanship, systematically according to scientific structure, and ease in understanding questions.

Based on the data obtained at the one to one evaluation stage, the results of this development are expressed as practical expectations because all aspects have been categorized as practical or very practical. The devices that have been tested for practicality expectations are then revised again based on input and comments from students.

Based on the assessment of the implementation of the CSP in a small group test has been carried out well. In general the steps of learning activities have been carried out well and systematically. There are several steps to learning activities that do not get optimal scores. The learning activities at the first meeting which were less optimal were in phase 1 (making problem formulations), phase 2 (making hypotheses), and phase 6 (making conclusions). Whereas at the meeting of 2 activities that did not get the maximum score was in phase 1 (making a problem statement), phase 3 (designing an experiment), and closing phase. This is because teachers get lots of questions from students about observing activities in LKPD. Some students' questions include learning material, learning steps and how to fill in answers to the LKPD, so that some students who are not supervised carry out activities that are not in line with the learning objectives.

Based on the assessment of the implementation of the RPP in a small group test the results have been obtained that the activities of students are classified as good. In general the steps of the students' activities have been well and systematically carried out. Even though there are still some that do not meet the expectations of the lesson plan, this is because students on a daily basis are not accustomed to applying the guided inquiry syntax, causing many to ask questions in the process of group activities.

There are two activities of face-to-face learners that have been carried out but not as expected in the RPP, which is not yet optimal in using LKPD to practice critical thinking skills. An increase in student activity is caused by students already getting used to learning activities in following the syntax of guided inquiry. Some students are still afraid of wrong about the procedures for filling the group LKPD. But in general the steps of teacher activities have been implemented well and systematically. The teacher has been able to optimally carry out learning activities according to the lesson plan at every face-to-face. This is inseparable from the advantages of learning tools used. The learning activities in the lesson plan are arranged in detail with the phases / syntax of guided inquiry, so as to guide and facilitate the teacher to apply the guided inquiry learning model. The category achieved by the teacher shows that during the learning the teacher has run all phases/syntax of guided inquiry.

Based on the results of observations of the activities of students at the beginning of the meeting still having difficulty writing the formulation of the problem to write down how it works. This is indicated by the large number of students asking questions and constraints on choosing the right words to formulate the problem so that guidance from the teacher must still be given. Questions frequently asked by students are about the work steps of LKPD that will be taken. Student questions begin with curiosity that comes from observations made. The teacher directs learning and guides students during learning through questions raised by the teacher and students themselves. Students' questions come from curiosity about what is done and guide students to do learning activities.

\section{Effectiveness of Learning Tools}

Based on the assessment of learning outcomes indicate the learning device is quite effective. The effectiveness of the use of learning tools developed can be seen from the increase in cognitive learning outcomes and critical thinking skills and students' social skills. The results of this study support the results of previous studies by Bilgin [10], Koksal \& Barberoglu [11], Zehra \& Nermin [12] and Ali [13] who state that by using guided inquiry learning the learning outcomes of students become better. In line with the results of research previously conducted by Chusni \& Widodo [13], Yunita [15], Dewi, et al. [16] which states that cognitive learning outcomes of students have increased through guided inquiry learning.

Critical thinking skills and cognitive learning outcomes have increased because learning with guided inquiry-based learning tools makes them trained in building interconnected scientific knowledge. According to Matthew \& Kenneth's [17] research findings students become active because guided guided learning is trained to build team spirit so that they have responsibility for each other in natural exploration. Active learning strategies have a positive effect on student motivation [18]. According to Kostelníková \& Ožvoldová [19] research findings guided inquiry can motivate students in the learning process so that they help students have thinking skills, and build knowledge.

The impact of motivation makes student learning outcomes optimal. Motivation is directly proportional to student learning outcomes. Students who have high motivation tend to achieve good learning outcomes [20]. There have been many studies 
proving a positive correlation between motivation and learning outcomes. Some of them are the results of research Zerpa, et al. [21], Noureen, et al. [22], and Amrai, et al. [23] state that motivation is significantly correlated with student learning outcomes.

The findings of this study support the findings and results of previous studies. Lonher, et al. [13] found that guided inquiry learning requires active participation of students so that they are able to construct and evaluate their own hypotheses, and obtain their own conclusions. Supports the results of Ali Abdi's research [13] which states that through inquiry learning the achievement of students is higher compared to conventional learning models.

Critical thinking skills in the field test showed that all categories of critical thinking skills tested were categorized as good. But there are no students who get a very good category score. Through experimental activities obtained that the results of critical thinking skills include: (1) Formulating problems with good categories; (2) Making a hypothesis with a good category; (3) Designing experiments/observations with good categories; (4) Collecting data in either category; (5) Analyzing data in either category; (6) Making conclusions in either category. This shows that by using the developed learning tools, students are able to perform critical thinking skills well. These results are in line with Wulandari \& Rustaman [24], that the activities of formulating problems, making hypotheses, designing experiments, collecting data, analyzing data, and formulating conclusions are things that can be done to train students' critical thinking.

Characteristic behavior data shows that students have been diligent and careful in various practicum activities carried out. most students get a score with a good category. This shows that students have been able to be diligent and careful in practicing. One of the reasons is because they were previously told that being diligent and careful is an assessment that will be observed by the teacher when the students do the practicum.

The social skills of the students measured in this study are collaboration and expressing opinions. The results of the assessment of collaborating students have shown good results. Likewise, the attitude of expressing an opinion is already good. Students can get a good assessment of social skills because they are encouraged by the teacher to work together in groups and dare to express opinions during discussions in order to obtain a good assessment. Based on the results of observations of students' activities during the learning process shows that the learning device developed can lead to positive activities and reduce the negative activities of students. This is in accordance with research Erdemir \& Bakirci [25] which states that studying science can develop a positive attitude.
Based on observational data it is known that students' responses to learning tools developed are very positive and can be applied in other classes, supported by previous research Dewi, et al. [26, 27] concluded that if students' response data to teaching materials and worksheets developed was positive, then this meant students were interested, understood, and easy when learning to use teaching materials and worksheets that were developed. Based on the results of the test of the effectiveness of expectations and actual effectiveness it can be concluded that the learning tools developed are declared effective and can be used or applied to learning in the classes of MTs Muhammadiyah 3 AlFurqan Banjarmasin.

\section{CONCLUSION}

Based on the results of the study it can be concluded that:

1. The Natural Science learning tool uses a guided inquiry model about the subject changes around which is valid, including syllabus, lesson plans, LKPD, teaching materials, cognitive LP obtained from three experts

2. The Natural Science learning tool uses a guided inquiry model on the topic of changes in objects around which is practically obtained from the implementation of lesson plans (preliminary activities, core activities, and closing) categorized as good.

3. The Natural Science learning tool uses the guided inquiry model of the topic of change in objects around which is effective, including the learning outcomes of students who have completed 25 pupils with a percentage of completeness of $89.3 \%$ and has reached the KKM set by the school at 75, critical thinking skills of categorized students good, character behavior includes diligent aspects of categorized good and careful aspects categorized as good, social skills include aspects of cooperating well categorized and aspects of expressing good categorized opinions, and good categorized student responses.

\section{REFFERENCE}

1. Pribadi, B. A. (2011). Model assure untuk mendesain pembelajaran sukses. Jakarta: Dian Rakyat.

2. TIMSS. (2011). Survey International TIMSS (http://litbang.kemdikbud.go.id/index.php/surveiinternasional-timss, diakses tanggal 7 Desember 2014).

3. Gurria, A. (2016). PISA 2015 Result in Focus. OECD Organization.

4. PUTRA, I. W. E., Sadia, I. W., \& Suastra, I. W. (2014). Pengaruh Model Pembelajaran Perubahan Konseptual terhadap Pemahaman Konsep Siswa Ditinjau dari Gaya Kognitif. Jurnal Pendidikan dan Pembelajaran IPA Indonesia, 4(1).

5. Rooney, C. (2012). How am I using inquiry-based learning to improve my practice and to encourage 
higher order thinking among my students of mathematics?. Educational Journal of Living Theories, 5(2).

6. Zaini, M., \& Asnida, D. J. (2016). The development of science-biology learning instrument oriented to mangrove forest for junior high school students. In Proceeding Biology Education Conference: Biology, Science, Enviromental, and Learning (Vol. 12, No. 1, pp. 134-141).

7. Fang, S. C., Hsu, Y. S., Chang, H. Y., Chang, W. H., Wu, H. K., \& Chen, C. M. (2016). Investigating the effects of structured and guided inquiry on students' development of conceptual knowledge and inquiry abilities: a case study in Taiwan. International Journal of Science Education, 1-27.

8. Minner, D. D., Levy, A. J., \& Century, J. (2010). Inquiry-Based instruction what is it and does it matter? Results from a research synthesis years 1984 to 2002. Journal of Research in Science Teaching, 47(4), 363-496.

9. Maslyni. (2016). Pengembangan Modul IPA Berorientasi Lingkungan pada Konsep Polusi dan Limbah untuk Melatihkan Keterampilan Berpikir Kritis Siswa SMKN 1 Daha Selatan. Banjarmasin: Prodi Pascasarjana IPA ULM.

10. Bilgin, I. (2009). The Effect of Guided Inquiry Instruction Incorporating a Cooperative Learning Approach on University Students' Achievement of Acid and Bases Concepts and Attitude toward Guided Inquiry Instruction. Scientific Research and Essay, 4(10), 1038-1046.

11. Koksal, E. A., \& Barberoglu, G. (2014). The effect of guided-inquiry instruction on 6th grade turkish students' achievement, science process skills, and attitudes toward science. International Journal of Science Education, 36(1), 66-78.

12. Özdilek, Z., \& Bulunuz, N. (2009). The effect of a guided inquiry method on pre-service teachers' science teaching self-efficacy beliefs. Journal of Turkish Science Education, 6(2), 24-42.

13. Abdi, A. (2014). The Effect of Inquiry-Based Learning Method on Students' Academic Achievement in Science Course. Universal journal of educational Research, 2(1), 37-41.

14. Chusni, M. M. (2013, June). Widodo. 2013.“. In Pengembangan LKS Berbasis Kerja Laboratorium untuk Meningkatkan Ketrampilan Proses dan Hasil Belajar Siswa SMP Muh Muthilan. Prosiding Seminar Nasional Sains dan Pendidikan Sains VIII, UKSW ISSN (pp. 20870922).

15. Yunita, E. (2016). Pengembangan Perangkat Pembelajaran Menggunakan Model Inkuiri Terbimbing Topik Klasifikasi Makhluk Hidup di SMP. JINoP (Jurnal Inovasi Pembelajaran), 2(1), 282-292.
16. Dewi, K., Sadia, W., \& Ristiati, N. P. (2013). Pengembangan perangkat pembelajaran ipa terpadu dengan setting inkuiri terbimbing untuk meningkatkan pemahaman konsep dan kinerja ilmiah siswa. Jurnal Pendidikan dan Pembelajaran IPA Indonesia, 3(1).

17. Matthew, B.M., dan Kenneth, I.O. (2012). A Study on the Effect of Guided Learning Teaching Method on Students Achievement in Logic, International Researcher, 2(1), 135-40.

18. Ellez, M. A. (2004). The Relationships among Effective Learning, Use of Strategy, Mathematical Achievement, Motivation and Gender (Doctoral dissertation, PhD Dissertation).

19. Kostelníková, M., \& Ožvoldová, M. (2013). Inquiry in Physics Classes by Means of Remote Experiments. Procedia-Social and Behavioral Sciences, 89, 133-138.

20. Slavin, R. E. (2011). Psikologi pendidikan teori dan praktik. Jakarta: Indeks.

21. Sarwar, G. S., Zerpa, C., Hachey, K., Simon, M., \& Van Barneveld, C. (2012). Teaching practices and student motivation that influence student achievement on large-scale assessments. International Journal of Education, 4(3), 88.

22. Awan, R. U. N., Noureen, G., \& Naz, A. (2011). A Study of Relationship between Achievement Motivation, Self Concept and Achievement in English and Mathematics at Secondary Level. International Education Studies, 4(3), 7279.

23. Amrai, K., Motlagh, S. E., Zalani, H. A., \& Parhon, H. (2011). The relationship between academic motivation and academic achievement students. Procedia-Social and Behavioral Sciences, 15, 399-402.

24. Wulandari, D.F., \& Rustaman, N.Y. (2015). Pengembangan Alat Ukur Keterampilan Berpikir Kritis dan Kreatif pada Pembelajaran B'Better Pokok Bahasan Gelombang Bunyi. Prosiding Seminar Nasional IPA VI pendidikan IPA FMIPA UNNES 25 April 2015.

25. Erdemir, \& Bakirci. (2009). The Change and the Development of Attitudes of Science Teacher Candidates Towards Science Branches. Kastamonu Educational Journal, 17(1): 161-170.

26. Dewi, A. P. (2014). Pengembangan Modul IPA Terpadu Untuk SMP/MTs Berbasis Eksperimen Pada Tema Fotosintesis Untuk Memberdayakan Keterampilan Proses Sains (Doctoral dissertation, UNS (Sebelas Maret University)).

27. Löhner, S., Van Joolingen, W. R., Savelsbergh, E. R., \& van Hout-Wolters, B. (2005). Students' reasoning during modeling in an inquiry learning environment. Computers in Human Behavior, 21(3), 441-461. 